\title{
Hubungan Panjang-Bobot dan Faktor Kondisi Ikan Baronang (Siganus sp.) di Perairan Tondonggeu Kecamatan Abeli Kota Kendari
}

\author{
Length-Weight Relationship and Ponderal Index of Rabbitfish (Siganus sp.) \\ in Tondonggeu Water Abeli Subdistrict Kendari City
}

\author{
Sudarno $^{1)}$, Asriyana ${ }^{2 *}$, Hasnia Arami ${ }^{3)}$ \\ 1) Program Studi Manajemen Sumber Daya Perairan FPIK Univ. Halu Oleo, Kendari, Indonesia \\ 2) Jurusan Manajemen Sumber Daya Perairan FPIK Univ. Halu Oleo, Kendari, Indonesia \\ 3) Jurusan Manajemen Sumber Daya Perairan FPIK Univ. Halu Oleo, Kendari, Indonesia \\ Corresponding author $^{*}$ : asriyana@uho.ac.id
}

\begin{abstract}
This study aimed to analyze relationship length-weight and the ponderal index of rabbitfish (Siganus sp.) in Tondonggeu Waters, Abeli District, Kendari City. This research was conducted for three months from March to May 2014. Sampling points was based on the representation of the location of trap nets in Tondonggeu waters. Trap nets used have 1.5 inches of mesh size and 1 inch of crib. The results study tabulated and analyzed descriptively. The results of measurements of environmental parameters obtained by the temperature range 29$30^{\circ} \mathrm{C}$; salinity $30-31 \%$; acidity $(\mathrm{pH}) 6.0-7.0$; water velocity $0.048-0.068 \mathrm{~m} / \mathrm{s}$; and dissolved oxygen $6.3-7.73$ $\mathrm{mg} / \mathrm{L}$. A total of 1,059 fish individuals was caught with ranged from 70.0-190.0 mm. The relationship lengthweight of male rabbitfish showed isometric growth patterns on March $(b=2.99)$; negative allometric April $(b=$ 2.87) and May $(b=2.75)$, respectively. The type of growth of female rabbitfish showed a positive allometric pattern on March $(b=3.07)$; and isometric on April $(b=2.96)$ and May $(b=2.98)$, respectively. Ponderal index of male rabbitfish range from 0.89 to 1.17 and females from 0.81 to 1.80 . Females were generally in better condition than the males.
\end{abstract}

Keywords : Rabbitfish, negative allometric, isometric, Tondonggeu

\begin{abstract}
ABSTRAK
Penelitian ini bertujuan untuk menganalisis hubungan panjang-bobot dan faktor kondisi ikan baronang (Siganus sp.) di perairan Tondonggeu Kecamatan Abeli Kota Kendari. Penelitian dilaksanakan selama tiga bulan yaitu dari bulan Maret sampai Mei 2014. Penentuan titik pengambilan sampel berdasarkan keterwakilan lokasi alat tangkap sero di perairan Tondonggeu. Sero yang digunakan mempunyai mata jaring penajuh 1,5 inci dan bunuhan 1 inci. Hasil penelitian ditabulasi dan dianalisis secara deskriptif. Parameter lingkungan menunjukkan kisaran suhu $29-30^{\circ} \mathrm{C}$; salinitas 30-31\% ; derajat keasaman $(\mathrm{pH})$ 6,0-7,0; kecepatan arus 0,048-0,068 m/detik; dan oksigen terlarut $6,3-7,73 \mathrm{mg} / \mathrm{L}$. Jumlah ikan yang terkumpul sebanyak 1.059 ekor dengan kisaran panjang total 70,0-190,0 mm. Hubungan panjang-bobot ikan baronang jantan menunjukkan pola pertumbuhan isometrik saat bulan Maret $(b=2,99)$; allometrik negatif saat bulan April $(b=2,87)$ dan Mei $(b=2,75)$. Tipe pertumbuhan ikan baronang betina menunjukkan pola allometrik positif saat bulan Maret $(b=3,07)$; isometrik saat bulan April $(b=2,96)$ dan Mei $(b=2,98)$. Faktor kondisi ikan baronang jantan berkisar $0,89-1,17$ dan betina $0,81-1,80$. Ikan betina mempunyai kondisi lebih baik daripada ikan jantan.
\end{abstract}

Kata kunci : Baronang, allometrik positif, isometrik, Tondonggeu

DOI: http://dx.doi.org/10.33772/jspi. 


\section{PENDAHULUAN}

Tondonggeu merupakan salah satu kelurahan yang berada di wilayah Kecamatan Abeli Kota Kendari. Daerah ini memiliki luas wilayah $450 \mathrm{Ha}$ yang terbagi menjadi tiga lingkungan yaitu Lingkungan I, II, dan III dengan panjang garis pantai $\pm 2,50 \mathrm{~km}^{2}$ (Badan Pusat Statistik-BPS, 2009). Tondonggeu merupakan daerah yang sebagian besar memiliki potensi wilayah pesisir yang cukup menunjang kegiatan perikanan.

Perairan Tondonggeu sebagai perairan semi terbuka memiliki tipe substrat berpasir, pasir berlumpur, dan bercampur pecahan karang, serta memiliki hamparan lamun dan terumbu karang. Selain itu kondisi perairan tersebut relatif tenang, bentuk topografi dasar perairan cukup landai, sehingga menjadikan perairan ini sangat menunjang usaha perikanan dengan alat tangkap sero.

Salah satu sumber daya ikan yang terdapat di perairan Tondonggeu yaitu ikan baronang. Ikan ini termasuk dalam famili Siganidae, merupakan jenis ikan demersal yang hidup di dasar atau dekat dengan dasar perairan, serta banyak ditemukan di daerah terumbu karang, padang lamun, dan mangrove (Safruddin, 2008; Kuiter and Tonozuka, 2001). Sebagai ikan demersal, ikan baronang banyak

Ikan baronang termasuk ikan ekonomis penting (Murniyani, 2013). Ikan baronang memiliki nilai gizi yang tinggi dan merupakan salah satu bahan pangan yang perlu dijaga dan dilestarikan untuk menunjang kebutuhan masyarakat yang semakin meningkat. Tingginya kegiatan penangkapan diduga telah menyebabkan sumber daya ikan baronang mengalami penurunan ukuran baik ukuran panjang maupun bobot. Oleh karena itu, diperlukan suatu pengelolaan sumber daya ikan baronang agar sumber daya tersebut berkelanjutan. Salah satu informasi dasar untuk menunjang upaya tersebut adalah informasi pola pertumbuhan dan faktor kondisi ikan baronang. Informasi tersebut diharapkan dapat menjadi tolak ukur dalam penangkapan ikan yang lestari dan berkelanjutan.

Hubungan panjang-bobot merupakan indikator penting dalam mempelajari sifat biologi, fisiologi, ekologi. Informasi ini dapat memberikan keterangan mengenai kondisi ikan dan menentukan apakah pertumbuhannya isometrik atau allometrik (Oscoz et al., 2005; Asriyana, 2015). Faktor kondisi dapat berupa suatu angka yang menunjukkan kegemukan ikan. Dari sudut pandang nutrisional, faktor kondisi merupakan akumulasi lemak dan perkembangan gonad (Le Cren, 1951); menunjukkan kondisi fisiologi ikan yang menerima pengaruh dari faktor intrinsik (perkembangan gonad dan cadangan lemak) dan faktor ekstrinsik (ketersediaan sumber daya makan dan tekanan lingkungan) (Nikolsky, 1969); dan dapat memberikan informasi tentang kapan ikan memijah (Weatherley \& Rogers, 1978; Hossain et al., 2006).

Sejauh ini, penelitian mengenai ikan baronang telah banya dilakukan dalam beberapa aspek, seperti aspek biologi dan komposisi jenis makanan (Ibrahim, 2002; Letsoin, 2006); hubungan morfometrik, panjang-bobot, dan faktor kondisi (Wambiji et al., 2008; Amelia, 2009; Anand \& Reddy, 2012); dan asosiasi ikan baronang dengan ekosistem lamun (Latuconsina $d k k$., 2011). Sementara penelitian mengenai hubungan panjangbobot dan faktor kondisi ikan baronang di perairan Tondonggeu Kecamatan Abeli Kota Kendari belum pernah dilakukan. Penelitian bertujuan untuk menganalisis hubungan panjang-bobot dan faktor kondisi ikan baronang (Siganus sp.) di perairan Tondonggeu Kecamatan Abeli Kota Kendari.

\section{METODE PENELITIAN}

Penelitian ini dilaksanakann selama tiga bulan, dari bulan Maret sampai Mei 2014. Pengambilan sampel menggunakan alat tangkap sero dengan penajuh berukuran mata jaring 1,5 dan 1,0 inci pada daerah bunuhan. Pengambilan dilakukan pada tiga buah sero agar mewakili karakterisitik populasi sampel (Tabel 1 dan Gambar $1)$.

Tabel 1. Letak titik pengambilan sampel, karakteristik titik pengambilan sampel dan titik koordinat

\begin{tabular}{clc}
\hline Lokasi & $\begin{array}{c}\text { Karakteristik Titik } \\
\text { Pengambilan } \\
\text { Sampel }\end{array}$ & Titik Koordinat \\
\hline \multirow{3}{*}{ I } & $\begin{array}{l}\text { Bersubstrat lumpur } \\
\text { berpasir yang } \\
\text { berdekatan dengan } \\
\text { ekosistem mangrove }\end{array}$ & $4^{0} 0^{\prime} 9,42^{\prime \prime}$ ' LS dan \\
& $122^{0} 37^{\prime} 58,86^{\prime \prime} \mathrm{BT}$ \\
II & $\begin{array}{l}\text { Bersubstrat pasir } \\
\text { yang berada di } \\
\text { ekosistem lamun }\end{array}$ & $4^{0} 0^{\prime} 5,50^{\prime \prime}$ LS dan \\
& $122^{0} 38^{\prime} 4,77^{\prime}$ BT \\
\end{tabular}



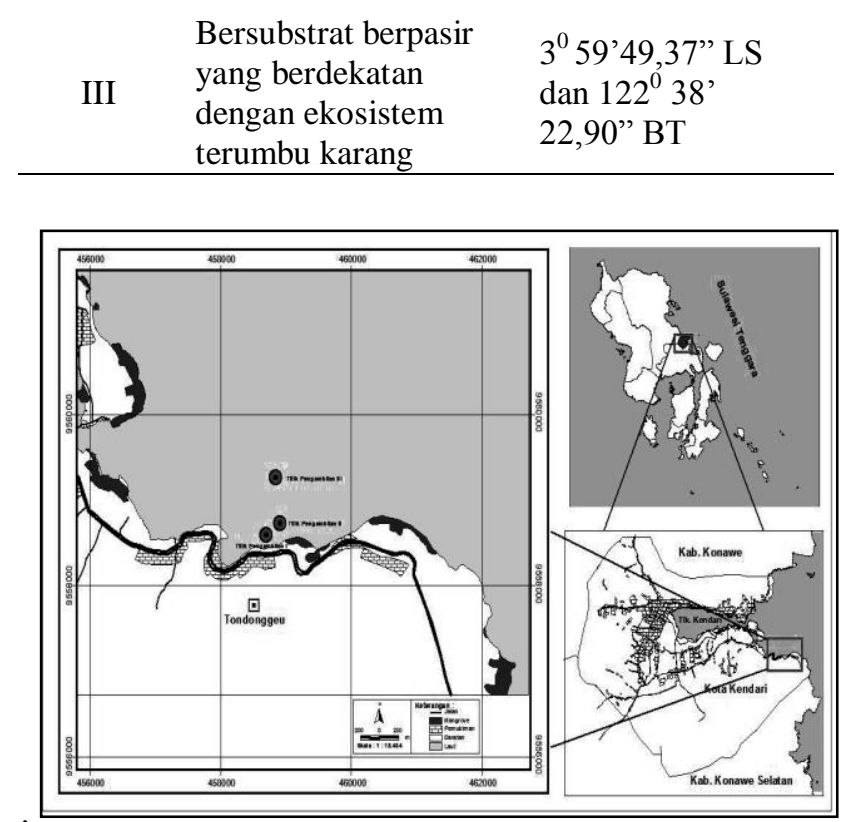

Gambar 2. Lokasi penelitian perairan Tondonggeu

Pengambilan sampel dilakukan setiap dua minggu sekali (berdasarkan fase pasang dalam satu bulan yaitu saat pasang purnama dan pasang perbani) selama tiga bulan, sehingga total data keseluruhan sebanyak 12 data. Alat tangkap yang digunakan adalah sero dengan ukuran mata jaring penajuh 1,5 inci dan bunuhan 1 inci. Semua ikan baronang yang tertangkap pada sero digunakan sebagai sampel.

Sampel ikan baronang yang tertangkap dikumpulkan dan diidentifikasi menurut Munroe et al. (1999) dan Carpenter \& Niem (1999). Ikan sampel kemudian diukur panjang totalnya (panjang ikan dari ujung terdepan bagian kepala hingga ujung terakhir bagian ekor) dengan menggunakan papan pengukur ikan berketelitian $0,5 \mathrm{~mm}$ dan ditimbang bobotnya dengan timbangan digital berketelitian 0,01 g. Ikan sampel kemudian dibedah untuk membedakan antara jantan dan betina, jantan ditandai dengan gonad yang berwarna putih sedangkan betina dapat ditandai dengan gonad berwarna kuning.

Parameter lingkungan seperti suhu, salinitas, kecepatan arus, dan $\mathrm{pH}$ diukur di lapangan, sedangkapan oksigen terlarut dianalisis di laboratorium dengan menggunakan metode titrasi Winkler. Pengukuran setiap parameter dilakukan disaat bersamaan dengan pengambilan sampel.
Sebaran frekuensi panjang diperoleh dengan mengelompokkan ukuran panjang tersebut ke dalam kelas-kelas panjang. Pengelompokkan ikan kedalam kelas panjang yaitu dengan menentukan range atau wilayah kelas, selang kelas dan batas-batas kelas ukuran berdasarkan data yang ada. Pembagian kelas ukuran panjang dan lebar selang kelas dihitung dengan persamaan Sudjana (2002) :

$$
\text { Jumlah kelas }=1+3,3 * \log (\mathrm{N}) \ldots \ldots(1)
$$

Lebar kelas $=\mathrm{P}_{\max }-\mathrm{P}_{\min } /$ Jumlah kelas........ (2)

Hubungan panjang dan bobot dihitung dengan menggunakan formula Tesch (1971); Asriyana (2015):

$$
\mathrm{W}=\mathrm{a} \mathrm{L}^{\mathrm{b}} \text {. }
$$

dengan $\mathrm{W}=$ Bobot ikan $(\mathrm{g}) ; \mathrm{L}=$ panjang total ikan (mm); a dan b adalah nilai konstanta yang diperoleh dari hasil perhitungan.

Uji t digunakan untuk menguji nilai b. Bi-la nilai $\mathrm{b} \neq 3$ berarti ikan mempunyai pola per-tumbuhan isometrik, sebaliknya bila $\mathrm{b}=3$ berarti pola pertumbuhan ikan bersifat allometrik (Walpole (1995).

$$
\mathrm{t}_{\text {hitung }}=\frac{\mathrm{b}-3}{\mathrm{sb}}
$$

Ponderal indeks atau faktor kondisi dihitung berdasarkan pola pertumbuhan dari hubungan panjang bobot. Jika pertumbuhan ikan isometrik, maka rumus yang digunakan adalah (Hile, 1936; Asriyana, 2015):

$$
\mathrm{K}=\frac{\mathrm{W}}{\mathrm{L}^{3}} \times 10^{5} .
$$

Jika tipe pertumbuhan bersifat alometrik $(b \neq 3)$, maka persamaan yang digunakan :

$$
K_{n}=\frac{\mathrm{W}}{\mathrm{aL}^{\mathrm{b}}}
$$

dengan $\mathrm{K}=$ faktor kondisi; $\mathrm{K}_{\mathrm{n}}=$ faktor kondisi relatif, $\mathrm{W}=$ bobot tubuh ikan $(\mathrm{g}) ; \mathrm{L}=$ panjang tubuh ikan $(\mathrm{mm})$; $\mathrm{a}$ dan $\mathrm{b}=$ nilai konstanta 


\section{HASIL DAN PEMBAHASAN}

Hasil

\section{Sebaran Frekuensi Panjang}

Ikan baronang yang diperoleh selama penelitian berjumlah 1.059 ekor yang terdiri dari 766 ekor ikan jantan dan 293 ekor ikan betina. Ikan baronang baik jantan maupum betina selama penelitian memiliki kisaran panjang total 70-190 mm. Berdasarkan hasil pengelompokkan kedalam kelas panjang, diperoleh 11 selang kelas panjang untuk jantan dan betina (Gambar 2)
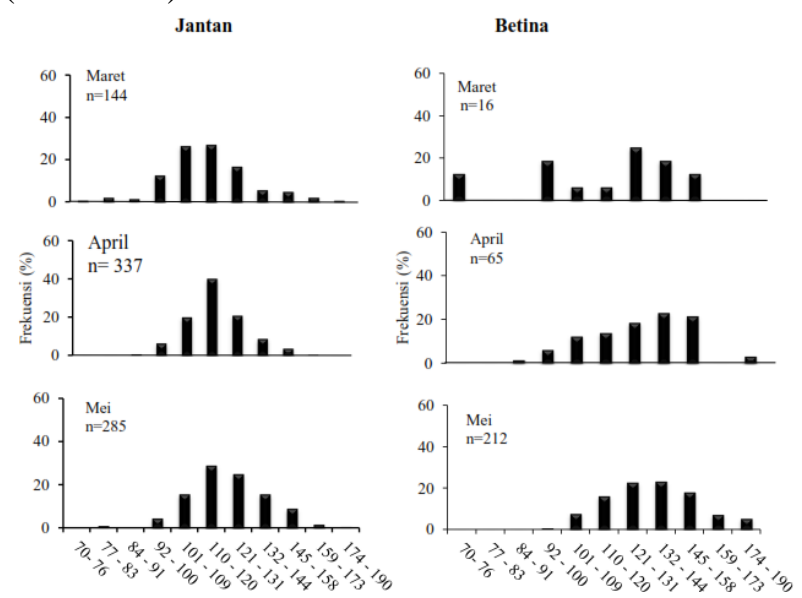

Gambar 2. Sebaran frekuensi panjang ikan jantan dan betina saat penelitian di perairan Tondonggeu

\section{Hubungan Panjang dan Bobot}

Hasil perhitungan panjang bobot tubuh ikan baronang jantan dan betina selama penelitian tertera pada Gambar 3. Berdasarkan hasil uji-t, ikan baronang jantan memiliki tipe pertumbuhan isometrik pada bulan Maret, dan tipe pertumbuhan allometrik negatif $(b<3)$ saat bulan April hingga Mei mempunyai. Sebaliknya, ikan baronang betina mempunyai tipe pertumbuhan allometrik positif (b >3) pada bulan Maret, dan tipe pertumbuhan isometrik pada bulan April dan Mei.

\section{Faktor Kondisi}

Hasil analisis faktor kondisi ditampilkan pada Tabel 2. Tabel 2 menunjukkan bahwa nilai faktor kondisi tertinggi untuk ikan jantan berada pada bulan April (berkisar 0,9450-1,1653) dan terendah saat bulan Mei (berkisar 0,8876-1,0890). Nilai faktor kondisi ikan betina ditemukan tertinggi saat bulan Maret (berkisar 1,1389-1,7897) dan terendah pada bulan Mei (berkisar 0,8107-1,0686).
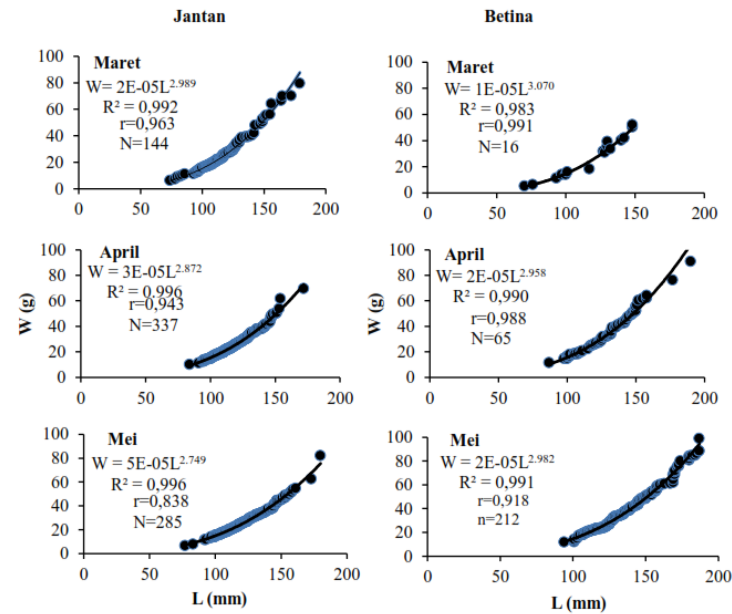

Gambar 3. Hubungan panjang bobot jantan dan betina saat penelitian di perairan Tondonggeu

Tabel 2. Faktor kondisi ikan baronang jantan dan betina saat penelitian di perairan Tondonggeu

\begin{tabular}{lcccccc}
\hline \multirow{2}{*}{ Bulan } & \multicolumn{3}{c}{ Jantan } & \multicolumn{3}{c}{ Betina } \\
\cline { 2 - 7 } & $\mathrm{N}$ & $\mathrm{FK}$ & Rerata & $\mathrm{N}$ & FK & Rerata \\
\hline Maret & 144 & $0,90-1,14$ & 1,00 & 16 & $1,13-1,78$ & 1,50 \\
April & 337 & $0,95-1,16$ & 1,00 & 65 & $0,87-1,12$ & 1,00 \\
Mei & 285 & $0,88-1,08$ & 1,00 & 212 & $0,81-1,06$ & 1,00 \\
\hline Keterangan : FK $=$ Faktor kondisi & & &
\end{tabular}

\section{Parameter lingkungan perairan}

Parameter lingkungan perairan yang diukur selama penelitian meliputi suhu, salinitas, $\mathrm{DO}, \mathrm{pH}$, dan kecepatan arus. Berdasarkan hasil pengukuran yang telah dilakukan diperoleh kisaran suhu (29-30 $\left.{ }^{0} \mathrm{C}\right)$; salinitas (30-31\%); DO $(6,17-7,73 \mathrm{mg} / \mathrm{L}) ; \mathrm{pH}$ (6-7); dan kecepatan arus $(0,0485-0,0680 \mathrm{~m} / \mathrm{d})$. Parameter lingkungan perairan yang diukur tertera pada Gambar 4.

\section{Pembahasan}

Sebaran frekuensi panjang ikan jantan tertinggi ditemukan pada selang kelas 110-120 mm saat bulan Maret, April, dan Mei, sementara panjang terendah ditemukan pada selang kelas $70-76 \mathrm{~mm}$ saat bulan Maret dan selang kelas ukuran 77-91 mm pada bulan April (Gambar 2). Secara umum, ikan baronang jantan dominan tertangkap pada ukuran 110-120 mm. 


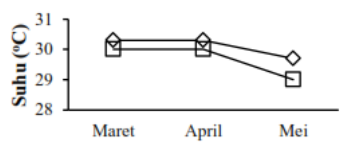

(1)

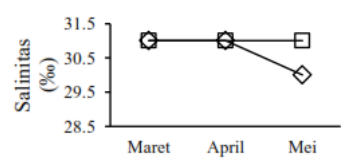

(2)

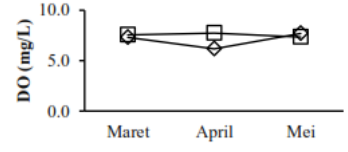

(3)

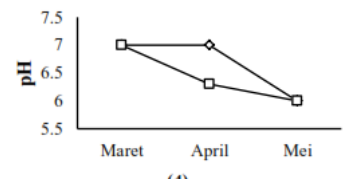

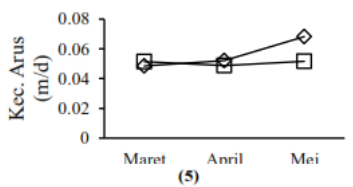

Gambar 4. Hasil pengukuran parameter lingkungan perairan

Banyaknya ukuran ikan yang tertangkap pada ukuran 110-120 $\mathrm{mm}$ ini disebabkan oleh mata jaring sero pada daerah bunuhan relatif kecil yaitu 1 inci. Walaupun ukuran yang tertangkap relatif kecil, namun saat pembedahan sampel ditemukan beberapa sampel memiliki tahap kematangan gonad (TKG) III dan IV (data belum dipublikasi). Hal ini menunjukkan bahwa di perairan Tondonggeu saat bulan Maret sampai Mei, ikan baronang yang tertangkap termasuk ikan dewasa yang sedang matang gonad dan siap memijah. Hal yang sama juga dilaporkan oleh Mayunar (1992) bahwa musim pemijahan baronang yang pertama berlangsung sekitar Januari sampai April dan musim pemijahan kedua berlangsung sekitar Juli sampai Oktober. Grandcaurt et al. (2006) melaporkan bahwa pemijahan ikan baronang terjadi antara April dan Juli.

Sebaran frekuensi panjang ikan betina saat bulan Maret tertinggi ditemukan pada selang kelas 121-131 mm dan terendah pada selang kelas 70-76 mm kecuali pada bulan April dan Mei tertinggi pada selang kelas 132-144 mm dan terendah pada ukuran 87-91 mm (Gambar 2). Ikan baronang betina selama penelitian memiliki kisaran panjang 70-190 $\mathrm{mm}$. Secara umum, ikan baronang betina memiliki ukuran yang lebih besar jika dibandingkan dengan ikan jantan. Hal ini terlihat dari ukuran ikan yang lebih banyak tertangkap pada ukuran 132-144 mm. Ukuran ini termasuk ukuran dewasa atau ukuran yang siap untuk melakukan pemijahan. Hal senada juga dilaporkan Letsoin (2006) di perairan Maluku bahwa berat ikan betina umumnya lebih besar daripada ikan jantan untuk menjamin fekunditas yang besar dalam stok dan perbedaan ukuran ini dicapai melalui ikan jantan yang matang gonad lebih cepat dan jangka hidupnya yang lebih singkat. Namun, hasil berbeda dilaporkan oleh Tuegeh $d k k$. (2012) di perairan Arakan, Minahasa bahwa ikan baronang (Siganus vermiculatus) jantan memiliki berat yang lebih besar dibandingkan ikan betina. Perbedaan tersebut disebabkan oleh perbedaan umur ikan atau pada saat masa pertumbuhan, energi dari makanan dipakai untuk pertumbuhan berat daripada pertumbuhan panjang atau juga disebabkan oleh ikan yang dijadikan sampel tersebut telah selesai memijah, atau telah memasuki tahap matang gonad, berat tubuh akan melebihi berat sebagaimana biasanya.

Rendahnya jumlah ikan baronang yang berukuran besar baik jantan maupun betina di Perairan Tondonggeu, dapat disebabkan oleh tekanan penangkapan. Kegiatan penangkapan yang terus menerus dilakukan oleh nelayan di Tondonggeu dengan menggunakan berbagai alat tangkap, terutama alat tangkap sero yang memiliki mata jaring pada dearah bunuhan yang cukup kecil (1 inci) dapat menyebabkan penurunan stok ikan baronang di perairan Tondonggeu. Hal tersebut terlihat dari ukuran ikan yang tertangkap baik jantan maupun betina selama periode penelitian memiliki ukuran 70-190 mm.

Selain itu, ikan baronang dominan tertangkap pada ukuran 110-120 mm (jantan); 121-131 mm dan 132- $144 \mathrm{~mm}$ (betina). Penurunan ukuran panjang ikan baronang yang tertangkap dan berada dalam keadaan matang gonad tersebut disebabkan oleh tekanan penangkapan. Senen et al. (2011) menyatakan ukuran pertama kali matang gonad pada ikan berbeda-beda, bahkan spesies yang sama namun berbeda habitatnya dapat matang gonad pada ukuran yang berbeda pula. Ukuran pertama kali matang gonad memiliki hubungan dengan pertumbuhan dan pengaruh lingkungan terhadap pertumbuhan serta strategi reproduksinya. Ikan yang mengalami tekanan karena penangkapan yang lebih banyak, cenderung matang gonad pada ukuran lebih kecil.

Beberapa penelitian menunjukkan bahwa ikan baronang memiliki ukuran panjang yang bervariasi di berbagai lokasi (Tabel 3). Variasi ukuran ikan dapat berbeda-beda, variasi ukuran tersebut dapat berubah disebabkan oleh tingkat 
kematangan gonad, jenis kelamin, dan musim pemijahan (Mayunar, 1992); perbedaan habitat, kondisi lingkungan, dan ketersediaan makanan (Asriyana, 2010; Latuconsina $d k k$., 2011; Asriyana, 2015). Dengan demikian, ketersediaan sumber makanan dan kondisi lingkungan yang baik menyebabkan ikan akan tumbuh dengan baik dan variasi ukurannya akan berbeda.

Tabel 3. Sebaran panjang ikan baronang di berbagai lokasi

\begin{tabular}{|c|c|c|c|}
\hline S. canaliculatus & $\begin{array}{c}\text { Ukuran } \\
\text { (TL, mm) }\end{array}$ & Lokasi & Pustaka \\
\hline Jantan & 200 & $\begin{array}{l}\text { Perairan } \\
\text { Singapore }\end{array}$ & Allen (1999) \\
\hline Betina & 300 & $\begin{array}{l}\text { Perairan } \\
\text { Australia }\end{array}$ & $\begin{array}{l}\text { Kuiter \&Tonozuka, } \\
\text { (2001) }\end{array}$ \\
\hline Betina & 230 & $\begin{array}{l}\text { Perairan } \\
\text { Malaysia }\end{array}$ & $\begin{array}{l}\text { Ahmad et al. } \\
\text { (2003) }\end{array}$ \\
\hline Betina & 330 & Perairan & Wambiji et al. \\
\hline Betina & 380 & laut Indian & (2008) \\
\hline Betina & 379 & Barat & \\
\hline Betina & 218 & Perairan & Lutuconsina $d k k$. \\
\hline Jantan & 205 & Telum & (2011) \\
\hline Jantan & 200 & $\begin{array}{l}\text { Ambon } \\
\text { dalam }\end{array}$ & \\
\hline Jantan & 200 & $\begin{array}{l}\text { Perairan } \\
\text { Saudi } \\
\text { Arabia }\end{array}$ & Mona et al. (2014) \\
\hline
\end{tabular}

Berdasarkan hasil analisis terhadap hubungan panjang bobot, ikan baronang jantan memiliki nilai konstanta $\mathrm{b}=2,989$ (Maret); 2,872 (April); dan 2,749 (Mei) seperti tertera pada (Gambar 6). Adapun ikan betina memiliki nilai konstanta $\mathrm{b}=$ 3,070 (Maret); 2,958 (April); dan 2,982 (Mei) seperti tertera pada (Gambar 3). Terdapat korelasi yang erat antara panjang total ikan dan bobot. Hal tersebut ditunjukkan oleh nilai koefisien korelasi (r) untuk masing-masing ikan, baik jantan maupun betina (Gambar 3).

Hubungan panjang-bobot tubuh ikan baronang jantan maupun betina memiliki koefisien korelasi (r) yang kuat hingga sangat kuat. Hal tersebut menunjukkan bahwa apabila panjang bertambah maka berpengaruh terhadap pertambahan bobotnya. Hal ini sesuai pernyataan Andy Omar (2005) bahwa apabila nilai koefisien korelasi berkisar 0,90-1,00 menunjukkan korelasi yang sangat kuat. Sugiyono (2013) menambahkan bahwa hubungan yang kuat dan positif, apabila nilai hasil koefisien korelasi mendekati 1, maka kedua peubah tersebut kuat dan terdapat korelasi yang tinggi antara keduanya.
Berdasarkan uji-t terhadap b, ikan jantan dan betina memiliki tipe pertumbuhan yang isometrik pada bulan Maret untuk (jantan) dan April hingga Mei untuk (betina), kecuali pada bulan April dan Mei ikan jantan memiliki tipe pertumbuhan yang allometrik negatif dan bulan Maret ikan betina memiliki tipe pertumbuhan allometrik positif. Hal ini menunjukkan bahwa pertambahan panjang ikan jantan bulan Maret dan betina di bulan April hingga Mei sebanding dengan pertambahan bobot tubuhnya. Namun, kondisi berbeda terlihat pada bulan April hingga Mei untuk ikan jantan yang memiliki tipe pertumbuhan allometrik negatif. Hal ini berarti bahwa pertambahan panjang lebih cepat daripada pertambahan bobot tubuhnya, kecuali pada bulan Maret untuk ikan betina memiliki tipe pertumbuhan allometrik positif yaitu pertambahan bobot lebih cepat daripada pertambahan panjang tubuh. Hal ini sesuai dengan pernyataan Effendie (2002) bahwa apabila $b=3$ maka pertumbahan ikan menunjukkan pola pertumbuhan isometrik, berarti pertambahan panjang tubuh dan bobot seimbang. Jika nilai $b<3$ menunjukkan tipe pertumbuhan allometrik negatif (pertambahan panjang tubuh lebih cepat daripada pertambahan bobot tubuh). Sebaliknya, jika $b>3$ menunjukkan tipe pertumbuhan allometrik positif (pertambahan bobot tubuh lebih cepat daripada pertambahan panjang tubuh).

Tidak selamanya ikan baronang jantan dan betina memiliki tipe pertumbuhan yang sama. Beberapa penelitian menunjukkan bahwa ikan dari family Siganidae tidak selalu memiliki tipe pertumbuhan isometrik dan allometrik negatif (Tabel 4).

Tabel 4. Nilai koefisien regresi dari (b) hubungan panjang dengan bobot baronang dari family Siganidae

\begin{tabular}{|c|c|c|c|c|}
\hline $\begin{array}{c}\text { Jenis/ } \\
\text { Kelamin }\end{array}$ & Nilai b & $\begin{array}{c}\text { Tipe } \\
\text { Pertumbuhan }\end{array}$ & Lokasi & Pustaka \\
\hline $\begin{array}{l}\text { S. canaliculatus } \\
\text { (betina) }\end{array}$ & 3,01 & Isometrik & $\begin{array}{c}\text { Perairan } \\
\text { Filipina }\end{array}$ & $\begin{array}{l}\text { Abes } \\
(1998)\end{array}$ \\
\hline $\begin{array}{l}\text { S. canaliculatus } \\
\text { (jantan) }\end{array}$ & 2,70 & $\begin{array}{l}\text { Allometrik } \\
\text { negatif }\end{array}$ & $\begin{array}{c}\text { Perairan } \\
\text { Saudi } \\
\text { Arabia }\end{array}$ & $\begin{array}{l}\text { Wassef } \\
\& \text { Hadry } \\
(2001)\end{array}$ \\
\hline $\begin{array}{l}\text { S. canaliculatus } \\
\text { (betina) }\end{array}$ & 3,03 & Isometrik & $\begin{array}{l}\text { Perairan } \\
\text { India }\end{array}$ & $\begin{array}{l}\text { Anad \& } \\
\text { Reddy } \\
(2012)\end{array}$ \\
\hline $\begin{array}{l}\text { S. luridus } \\
\text { (jantan) }\end{array}$ & 2,95 & $\begin{array}{l}\text { Allometrik } \\
\text { negatif }\end{array}$ & $\begin{array}{l}\text { Perairan } \\
\text { Libya }\end{array}$ & $\begin{array}{l}\text { Elbaraas } \\
(2014)\end{array}$ \\
\hline $\begin{array}{l}\text { S. rivulatus } \\
\text { (jantan) }\end{array}$ & 2,82 & $\begin{array}{c}\text { Allometrik } \\
\text { negatif }\end{array}$ & & \\
\hline
\end{tabular}


Variasi nilai (b) hubungan panjang bobot antar spesies ikan sangat bergantung pada kondisi lingkungan, musim, habitat, umur, jenis kelamin, dan kematangan gonad (Effendie, 2002); jumlah dan variasi ukuran ikan yang diamati, faktor lingkungan, perbedaan stok ikan dalam spesies yang sama, tahap perkembangan ikan, jenis kelamin, dan tingkat kematangan gonad (Harmiyanti, 2009); ketersediaan makanan, perkembangan gonad dan musim pemijahan (Yilmaz \& Polat, 2011; Asriyana, 2015).

Variasi perubahan nilai $b$ juga ditemukan pada beberapa ikan lainnya, seperti ikan spesies Sardinella fimbriata (Asriyana, 2010); Nemipterus tambuloides (Sjafei dan Robiyani, 2001); Upeneus moluccesnsis (Sjafei dan Susilawati, 2001); Aphareus rutilans (Hukom dkk., 2006); Acanthurus mata (Suwarni, 2009); Sardinella atricauda (Asriyana, 2015).

\section{Faktor Kondisi}

Berdasarkan Tabel 2, kisaran faktor kondisi ikan baronang jantan selama penelitian adalah 0,89 1,17 dan ikan baronang betina adalah 0,81-1,79. Berdasarkan nilai tersebut, faktor kondisi ikan betina relatif lebih besar $(\mathrm{FK}=1,79)$ dibandingkan ikan jantan $(\mathrm{FK}=1,17)$. Hal tersebut disebabkan oleh rerata bobot tubuh ikan betina relatif lebih besar dibandingkan ikan jantan; bobot gonad betina lebih besar daripada ikan jantan. Peningkatan nilai faktor kondisi terjadi saat gonad ikan berkembang dan mencapai puncaknya sebelum terjadi pemijahan. Hal ini sesuai pernyataan Effendie (2002), fluktuasi faktor kondisi pada ikan tidak hanya dipengaruhi oleh bobot gonad tetapi juga oleh aktivitas selama pematangan dan pemijahan. Hal yang sama juga ditemukan pada ikan spesies Sardinella fimbriata (Asriyana et al., 2011); Upeneus moluccesnsis (Sjafei \& Susilawati, 2001); Acanthurus mata (Suwarni, 2009).

Nilai faktor kondisi tertinggi ikan baronang betina $(\mathrm{FK}=1,79)$ ditemukan pada ikan yang berukuran $130 \mathrm{~mm}$ dengan bobot tubuh $39,32 \mathrm{~g}$ dan faktor kondisi terendah $(\mathrm{FK}=0,81)$ ditemukan pada ikan yang berukuran $101 \mathrm{~mm}$ dan bobot tubuh 12,18 g. Ikan baronang jantan mempunyai nilai faktor kondisi tertinggi $(\mathrm{FK}=1,17)$ ditemukan pada ikan yang berukuran $154 \mathrm{~mm}$ dan bobot tubuh $61,76 \mathrm{~g}$, dan faktor kondisi terendah $(\mathrm{FK}=0,89)$ ditemukan pada ikan yang berukuran $83 \mathrm{~mm}$ dan bobot 7,98 g.
Perbedaan nilai faktor kondisi tersebut disebabkan oleh variasi dari kisaran panjang dan bobot dari ikan baronang itu sendiri. Adanya variasi ukuran tersebut baik ukuran panjang maupun bobot akan memengaruhi ukuran ikan yang akan memijah. Hal ini didukung oleh pernyataan Rahardjo \& Simanjuntak (2007) bahwa pemijahan dapat menjadi salah satu penyebab terjadinya perubahan nilai faktor kondisi ikan. Lebih lanjut Lizama \& Ambrosia (2002) menambahkan bahwa faktor kondisi dapat berubah disebabkan oleh sumber energi utama digunakan untuk perkembangan gonad dan pemijahan.

Tabel 2 menunjukkan bahwa faktor kondisi rata-rata ikan baronang jantan dan betina selama periode penelitian pada bulan Maret sampai Mei masing-masing berkisar 1,00-1,00 (jantan) dan 1,00-1,50 (betina). Faktor kondisi relatif ikan jantan selalu lebih kecil dari pada ikan betina. Hal tersebut mengindikasikan bahwa kondisi ikan betina lebih baik dibandingkan ikan jantan selama periode penelitian. Tingginya faktor kondisi ikan jantan dan betina pada bulan Maret dan mulai menurun pada bulan April dan Mei dapat dipahami karena masa pemijahan ikan berlansung pada pada bulan Januari sampai April, kemudian pada April dan Mei ditemukan ikan jantan maupun betina telah selesai memijah. Hal ini sesuai pernyataan Rahardjo \& Simanjuntak (2007) bahwa nilai faktor kondisi ikan akan meningkat menjelang puncak musim pemijahan dan akan menurun setelah masa pemijahan.

Faktor kondisi merupakan turunan dari pertumbuhan yang menjelaskan tentang keadaan baik dari ikan dilihat dari segi kapasitas fisik untuk survival dan reproduksi (Effendie, 2002). Berdasarkan nilai faktor kondisi yang diperoleh, baik ikan jantan maupun betina menunjukkan bahwa pertumbuhan kedua ikan tersebut memiliki faktor kondisi yang cukup baik. Hasil penelitian lain yang tidak jauh berbeda dilaporkan oleh Amelia (2009) di Perairan Kulisusu bahwa nilai faktor ikan jantan dan betina ditemukan berbeda-beda untuk setiap kelompok ukuran, dan faktor kondisi ikan baronang cukup baik dengan nilai kisaran 1,04-1,25 (jantan) dan 0,97-1,19 (betina). Menurut Effendie (2002), faktor kondisi berkisar 3-4 menunjukkan tubuh ikan agak pipih dan bila berkisar 1-2 menunjukkan tubuh ikan kurang pipih. 


\section{KESIMPULAN}

Sebaran frekuensi panjang ikan baronang jantan maupun betina di perairan Tondonggeu didominasi ukuran dewasa. Hubungan panjang bobot ikan baronang selama penelitian memiliki tipe pertumbuhan allometrik negatif untuk jantan dan betina kecuali pada bulan Maret ikan betina memiliki tipe pertumbuhan isometrik. Berdasarkan nilai faktor kondisi, ikan baronang tergolong ikan yang pipih atau tidak gemuk; Parameter lingkungan perairan yang ditemukan selama penelitian pada bulan Maret sampai Mei masih dalam kondisi yang optimal untuk mendukung pertumbuhan dan perkembangan ikan baronang

\section{Ucapan Terima Kasih}

Penulis mengucapkan terima kasih kepada Dr. Bahtiar, S.Pi., M.Si dan La Ode Abdul Rajab Nadia, S.Pi., M.Sc atas saran perbaikan terhadap naskah ini; Fakultas Perikanan dan Ilmu Kelautan atas yang telah menyediakan semua fasilitas untuk melakukan penelitian ini.

\section{DAFTAR PUSTAKA}

Abes NP. 1998. Length-weight relationship of dominant species (Siganus canaliculatus) caught by the fish corral in Puerto Princesa Bay, Palawan,State Polytechnic College of Palawan. [Thesis]. Aquatic science and Technology institue, Puerto Princessa city, Philippines.

Ahmad ATB, Isa MM, Ismail MS, Yusof S. 2003. Status of demersal fishery resources of Malaysia. In: Assessment, management and future directions for coastal fisheries in Asian Countries. pp. 83-135.

Allen G. 1999. Marine fishes of South-East Asia; A guide for anglers and divers. Periplus Editions. Singapore. $292 \mathrm{p}$.

Amelia. 2009. Aspek reproduksi dan hubungan panjang berat ikan baronang (Siganus canaliculatus) di perairan Teluk Kulisusu Kecamatan Kulisusu Kabupaten Buton. [Skripsi]. Jurusan Perikanan Fakultas Perikanan dan Ilmu Kelautan. Universitas Halu Oleo. Kendari. 56 hal.

Anand M, Reddy PSR. 2012. Length-weight relationship of the whitespotted rabbitfish
Siganus canaliculatus (Park, 1797) from Gulf of Mannar, south India. Journal of the Marine Biological Association of India 54(1): 91-94.

Arami H, Mustafa A. 2010. Analisis selektivitas gillnet yang dioperasikan di perairan Lentea Kecamatan Kaledupa Selatan Kabupaten Wakatobi. Warta-Wiptek. 6 hal.

Asriyana. 2010. Pertumbuhan ikan tembang, Sardinella fimbriata Valenciennes (Pisces : Clupeidae) di Perairan Teluk Kendari. Makalah disampaikan dalam Seminar Nasional Tahunan VII Hasil Penelitian Perikanan dan Kelautan 2010 Yogyakarta, 24 Juli 2010. 13 hal.

Asriyana. 2015. Growth and condition factor of Bleeker's blacktip sardinella, Sardinella atricauda, Gunther 1868 (Pisces: Clupeidae) in Kendari Bay, Southeast Sulawesi. Indonesian Journal of Ichthyology 15(1): 77-86. [in Indonesian]

BPS. 2009. Kecamatan Abeli dalam Angka. Seksi Integrasi Pengolahan dan Diseminasi Statistik Badan Pusat Statistik Kota Kendari Sultra. 67 hal.

Effendie MI. 2002. Biologi Perikanan. Yayasan Pustaka Nusatama. Yogyakarta. 163 hal.

Elbaraasi H. 2014. Length-weight relationships for five lessepsian fish species from the coast of Benghazi, Libya (Southern Mediterranean). Journal agriculture, forestry, and fisheries 3(3): 178-180.

Grandcaurt, E., T. Al-Abdessalam., F. Francis., A. Al-Shamsi. 2006. Population Biology and Assesment of The Whitespotted Spinefoot, Siganus canaliculatus (Park, 1797), In the Southern Arabian Gulf. Journal Aplied Ichtyologi 23(1): 53-59.

Harmiyanti D. 2009. Analisis hasil tangkapan sumber daya ikan ekor kuning (Caesio cuning) yang didaratkan di PPI Pulau Pramuka, Kepulauan Seribu. Departemen Manajemen Sumber Daya Perairan, Fakultas Perikanan dan Ilmu Kelautan, Institut Pertanian Bogor. Bogor. 85 hal.

Hossain MY, Ahmed ZF, Jasmine S, Oscaoz J, Miranda R, Ohtomi J. 2006. condition lengthweight and length-weight relationships of the asian striped catfish Mystus Vittatus (Bloch, 1794) (Siluriformes: Bagridae) in the Mathabhanga River, Southwestern Bangladesh. 
Journal of Agricultural Science Academy Ichthyologi 22: 304-307.

Hukom FD, Purnama DR, Rahardjo MF. 2006. Tingkat kematangan gonad, faktor kondisi dan hubungan panjang-berat ikan tajuk (Aphareus rutilans cuvier, 1830) di perairan laut dalam Pelabuhan Ratu, Jawa Barat. Jurnal Iktiologi Indonesia 6(1): 1-9.

Ibrahim I. 2002. Studi beberapa aspek biologi dan komposisi jenis makanan ikan baronang Siganus canaliculatus di daerah padang lamun perairan pantai Desa Nusantara Kecamatan Banda Maluku. [Skripsi]. Fakultas Perikanan dan Ilmu Kelautan. Universitas Halu Oleo. Kendari. 58 hal.

Kuiter RH, Tonozuka T. 2001. Indonesian reef fishes. Part 3. Jawfishes Sunfishes. Zoonetic. Melbourne. Australia. 123 p.

Latuconsina H, Ambo-Rappe R, Nessa MN. 2011. Asosiasi ikan baronang (Siganus canaliculatus park, 1797) pada ekosistem padang lamun perairan Teluk Ambon Dalam. Fakultas Perikanan dan Ilmu Kelautan Universitas Darussalam, Ambon. 13 hal.

Le cren PA. 1951. Length-weight relationship and seasonal cycle in gonad weight and condition in the perch (Perca fluviatilis). Journal of Animal Ecology 20(2): 201-219.

Letsoin P. 2006. Beberapa aspek biologi ikan baronang (Siganus fuscescens) di perairan Desa Ngilngof Kecamatan Kei Kecil Kabupaten Maluku Tenggara Provinsi Maluku. [Skripsi]. Fakultas Perikanan dan Ilmu Kelautan. Universitas Sam Ratulangi. 52 hal.

Lizama M, De Los AP, Ambrosio AM. 2002. Condition factor ini nine spescies of fish of the charanidae family ini the Upper Parana River Floodplain, Brazil. Brazil. Journal Biologi 62 (1): 113-124.

Mayunar. 1992. Beberapa aspek biologi ikan baronang Siganus canaliculatus. Oseana 17(4):177-193.

Murniyati, A.S. 2003. Biologi 100 Ikan Laut Ekonomis Penting di Indonesia. Edisi ke-2. Sekolah Usaha Perikanan Menengah Negeri Tegal. 111 hal.

Al-Qishawe MMS, Al-Dawood T, Abahussain AA. 2014. Stock Assessment of White Spotted Rabbitfish (Siganus canaliculatus Park, 1797) in Jubail Marine Wildlife Sanctuary, Saudi
Arabia. International Journal of Fisheries and Aquatic Studies 1(6): 48-54.

Nikolsky GV. 1969. Theory of population dynamic as a biological background for relation exploitation and managemen of fishery resources. Olive and Body Publisher. United Kingdom. 323 p.

Oscoz J, Campos F, Escala MC. 2005. Weightlength relationships of some fish species of the Iberian Peninsula. Journal of Applied Ichthyology 21: 73-74.

Rahardjo MF, Simanjuntak CPH. 2008. Hubungan panjang bobot dan faktor kondisi ikan tetet, Johnius belangerii Cuvier (Pisces: Sciaenidae) di perairan pantai Mayangan, Jawa Barat. Jurnal Ilmu-ilmu Perairan dan Perikanan Indonesia 15(2):135-140.

Safruddin. 2008. Zona potensial penangkapan ikan baronang lingkis (Siganus canaliculatus) berdasarkan parameter oseanografi di perairan Pulau Tanakeke Kabupaten Takalar. Torani 18(4):325-331.

Senen B, Sulistiono, Ismudi M. 2011. Studi aspek biologi ikan layang deles (Decapterus macromosa) di perairan Banda Neira, Maluku. Prosiding Seminar Nasional: Pengembangan pulau-pulau kecil pp. 52-60.

Sjafei DS, Robiyani. 2001. Kebiasaan makanan dan faktor kondisi ikan kurisi (Nemipterus tumbuloides). di Perairan Teluk Labuan, Banten. Jurnal Iktiologi Indonesia 1(1): 7-11.

Sjafei DS, Susilawati R. 2001. Beberapa aspek biologi ikan biji nangka (Upeneus moluccensis) di Perairan Teluk Labuan, Banten. J35-39.urnal Iktiologi Indonesia 1(1):

Sudjana. 2002. Metode statistika. Tarsito. Bandung. (Edisi ke 6). $508 \mathrm{Hal}$.

Suwarni. 2009. Hubungan panjang-bobot dan faktor kondisi ikan butana Acanthurus mata (Cuvier, 1829) yang tertangkap di sekitar perairan pantai Desa Mattiro Deceng, Kabupaten Pangkajene Kepulauan, Provinsi Sulawesi Selatan. Torani (Jurnal Ilmu Kelautan dan Perikanan) 19(3): 160-165

Tuegeh S, Tilaar FF, Manu GD. 2012. Beberapa aspek biologi ikan baronang (Siganus vermiculatus) di perairan Arakan Kecamatan Tatapaan Kabupaten Minahasa Selatan. Jurnal Ilmiah Platax 1(1): 12-18. 
Walpole RE. 1995. Pengantar statistika, edisi ke-3. Gramedia Pustaka Utama. Jakarta. 515 hal.

Wambiji N, Ohtomi J, Bernerd F, Edward K, Nicholas K, Hossain, Yeamin M. 2008. Morphometric relationship and condition factor of Siganus stellatus, $S$. canaliculatus and $S$. sutur (Pisces: Siganidae) from the Western Indian Ocean Water. p 17.

Wassef EA, Hadry A. 2001. Some biological studies and gonadal development of rabbitfish (Siganus canaliculatus, Park) and Siganus spinus L. (F: Siganidae) from the Gulf Waters off Saudi Arabia, Journal KAU: Marine Sci.12: 189-208.

Weatherley AH, Rogers SC. 1978. Some aspecta in age and growth. In S.D. Gerking (ed), Ecology of freshwater production. Black-well Scientific Publication, Oxford. 52-73 p.

Yilmaz S, Polat N. 2011. Length-weight relationship and condition factor of pontic shad, Alosa immaculate (Pisces: Clupeidae) from the Southern Black Sea. Research Journal of Fisheries and Hydrobiology 6(2): 49-53. 